\title{
In vitro assessment of Pediococcus acidilactici Kp10 for its potential use in the food industry
}

\author{
Sahar Abbasiliasi ${ }^{1,2}$, Joo Shun Tan ${ }^{3}$, Fatemeh Bashokouh4 ${ }^{4}$, Tengku Azmi Tengku Ibrahim,5, Shuhaimi Mustafa ${ }^{1,2}$, \\ Faezeh Vakhshiteh ${ }^{4}$, Subhashini Sivasamboo ${ }^{1}$ and Arbakariya B. Ariff ${ }^{*}$
}

\begin{abstract}
Background: Selection of a microbial strain for the incorporation into food products requires in vitro and in vivo evaluations. A bacteriocin-producing lactic acid bacterium (LAB), Pediococcus acidilactici Kp10, isolated from a traditional dried curd was assessed in vitro for its beneficial properties as a potential probiotic and starter culture. The inhibitory spectra of the bacterial strain against different gram-positive and gram-negative bacteria, its cell surface hydrophobicity and resistance to phenol, its haemolytic, amylolytic and proteolytic activities, ability to produce acid and coagulate milk together with its enzymatic characteristics and adhesion property were all evaluated in vitro.
\end{abstract}

Results: P. acidilactici Kp10 was moderately tolerant to phenol and adhere to mammalian epithelial cells (Vero cells and ileal mucosal epithelium). The bacterium also exhibited antimicrobial activity against several gram-positive and gram-negative food-spoilage and food-borne pathogens such as Listeria monocytgenes ATCC 15313, Salmonella enterica ATCC 13311, Shigella sonnei ATCC 9290, Klebsiella oxytoca ATCC 13182, Enterobacter cloaca ATCC 35030 and Streptococcus pyogenes ATCC 12378. The absence of haemolytic activity and proteinase (trypsin) and the presence of a strong peptidase (leucine-arylamidase) and esterase-lipase (C4 and C8) were observed in this LAB strain. P. acidilactici Kp10 also produced acid, coagulated milk and has demonstrated proteolytic and amylolactic activities.

Conclusion: The properties exhibited by P. acidilactici Kp10 suggested its potential application as probiotic and starter culture in the food industry.

Keywords: Pediococcus acidilactici Kp10, Probiotic, Starter culture, Adhesion property, Proteolytic, Food-borne pathogens, Food industry

\section{Background}

The importance of proper selection of the bacterial strains for incorporation in food products is related to the considerable variations of the beneficial properties among different strains. Lactic acid bacteria (LAB) which are used worldwide have been focused in recent years for a variety of fermented foods production [1].

LAB play an important role in improving the nutritional and keeping qualities of foods by virtue of the organic acids produced during fermentation of the raw

\footnotetext{
*Correspondence: arbarif@upm.edu.my

'Department of Microbiology, Faculty of Biotechnology and Biomolecular Sciences, Universiti Putra Malaysia, 43400 UPM Serdang, Selangor, Malaysia

Full list of author information is available at the end of the article
}

materials [2]. At the industrial scale, short fermentation duration is preferred in order to increase the plant output as well as to reduce microbial contamination. The use of $L A B$ as a starter culture in food fermentation will increase the fermentation rates and also will improve product quality [3] due to $\mathrm{LAB}$ versatile metabolic characteristics such as acidification and proteolytic activities and ability to synthesize metabolites such as bacteriocin $[4,5]$. Thus, the isolation and characterization of new strains of LAB for broader industrial applications is currently of industrial importance.

LAB species presence in traditional foods of Southeast Asian countries have not been extensively investigated and there is every likelihood that some species could be 
of commercial potential [1]. With the realization that there is a need to identify new strains with useful characteristics, in our previous study we had identified and characterized the LAB strain with ability to produce bacteriocin-like inhibitory substances (BLIS) for potential applications in the food industry. The isolate, $P$. acidilactici $\mathrm{Kp} 10$, could be a potential probiotic as it exerted beneficial and positive effects on the intestinal flora which included tolerance to bile salts $(0.3 \%)$ and acidic conditions $(\mathrm{pH} 3)$, produced $\beta$-galactosidase, stable in a wide range of $\mathrm{pH}(2-$ 9) and not resistant to vancomycin. Most interesting, the LAB strain showed the highest level of BLIS activity against Listeria monocytogenes, a virulent food pathogenic bacterium. To further substantiate its probiotic potential and application as a starter culture the present study further evaluated in vitro other physicochemical properties of $P$. acidilactici Kp10 which include inhibitory spectra of activities against different gram-positive and gram negative bacteria, cell surface hydrophobicity, resistance to phenol, haemolytic, amylolytic and proteolytic activities, ability to produce acid and coagulate milk and enzymatic characterization along with its adhesive properties.

\section{Methods}

\section{Microorganism and maintenance}

Isolation and characterization of the bacterium, $P$. acidilacticiKp10, used in this study were as described previously [1]. The culture was maintained on agar slopes at $4{ }^{\circ} \mathrm{C}$ and prior to its use in the present study the culture was sub-cultured twice in M17 broth (Merck, Darmstadt, Germany).

\section{Determination of probiotic properties Inhibitory activity}

The inhibitory activities of $P$. acidilactici Kp10 against different gram-positive and gram-negative bacteria (Listeria monocytogenes ATCC 15313, Salmonella enterica ATCC 13311, Shigella sonnei ATCC 9290, Klebsiella oxytoca ATCC 13182, Enterobacter cloaca ATCC 35030, Streptococcus pyogenes ATCC 12378) were determined according to the method as described in our previous study. Briefly, antimicrobial activity of $P$. acidilactici $\mathrm{Kp} 10$ was assessed by the agar well diffusion method using cell-free culture supernatants (CFCS). P. acidilactici Kp10 was grown in M17 broth at $30{ }^{\circ} \mathrm{C}$ for $24 \mathrm{~h}$ and the cultures were centrifuged at 12,000 g for $20 \mathrm{~min}$ at $4{ }^{\circ} \mathrm{C}$ (rotor model 1189, Universal 22R centrifuge, Hettich AG, Switzerland).

One hundred $\mu \mathrm{L}$ of the CFCS was placed into $6-\mathrm{mm}$ wells of agar plates previously seeded with $1 \%(v / v)$ actively growing test strains. The plates were incubated at $37^{\circ} \mathrm{C}$ for $24 \mathrm{~h}$ for the growth of test strains. After $24 \mathrm{~h}$, the growth inhibition zones were measured, and the antimicrobial activity ( $\mathrm{AU} \mathrm{mL} \mathrm{m}^{-1}$ ) was calculated as described previously [6].

\section{Adhesion of $P$. acidilactici Kp10 on mammalian epithelial cells Adhesion of $P$. acidilactici Kp10 to vero cells}

Assessment of the adhesion of $P$. acidilactici Kp10 to Vero cells (African green monkey kidney cell line, ATCC CCL81) was performed by the method as described previously [7] with some modifications. Vero cells were cultured in Roswell Park Memorial Institute Medium (RPMI; Gibco, Grand Island, NY, USA) supplemented with $10 \%(\mathrm{v} / \mathrm{v})$ fetal calf serum, $100 \mathrm{U} / \mathrm{mL}$ penicillin and $100 \mathrm{mg} / \mathrm{mL}$ streptomycin (Sigma, Switzerland). The cell lines were maintained in a humidified incubator (Binder, Tuttlingen, Germany) at $37{ }^{\circ} \mathrm{C}$ in atmosphere of $5 \% \mathrm{CO}_{2}$ and $95 \%$ air. Cells with $80-85 \%$ confluence were washed three times with sterile phosphate-buffered saline (PBS: $\mathrm{NaCl}, 0.8, \mathrm{~K}_{2} \mathrm{HPO}_{4}, 0.121, \mathrm{KH}_{2} \mathrm{PO}_{4}, 0.034, \mathrm{pH}$ 7.2) and transferred $\left(10^{5}\right.$ cells $\left./ \mathrm{mL}\right)$ onto cover slips placed in sixwell plates containing fresh culture medium. The plates were incubated at $37{ }^{\circ} \mathrm{C}$ in an atmosphere of $5 \% \mathrm{CO}_{2}$ and $95 \%$ air. Cell monolayers $\left(10^{5}\right.$ cells $\left./ \mathrm{mL}\right)$ on glass cover slips were washed three times with PBS. Prior to the adhesion test, overnight culture of $P$. acidilactici Kp10 was harvested and washed three times with PBS and centrifuged for $10 \mathrm{~min}$ at $3000 \times \mathrm{g}$. The bacterial cells $\left(1 \times 10^{9} \mathrm{CFU} / \mathrm{mL}\right.$ in PBS) were resuspended in $1 \mathrm{~mL}$ of Dulbecco's modified Eagle medium (DMEM) and transferred to the washed monolayer cells on cover slips, placed in six-well plates and incubated at $37{ }^{\circ} \mathrm{C}$ in an atmosphere of $5 \% \mathrm{CO}_{2}$ and $95 \%$ air for $1 \mathrm{~h}$.

For scanning electron microscopy (SEM) examination, the cells were fixed in $2.5 \%$ glutaraldehyde in $0.1 \mathrm{M}$ sodium cacodylate buffer for 4-6 h and washed thrice in sodium cacodylate buffer. Samples were then postfixed in $1 \%$ aqueous osmium tetroxide, dehydrated in ascending grades of acetone concentrations (30, 50, 75, 80, 95 and $100 \%)$ critically point-dried and sputter coated with gold palladium.

\section{Adhesion of P. acidilactici Kp10 to ileal mucosal epithelium}

The method of Mäyrä-Mäukinen \& Gyllenberg, [8] with slight modifications was employed to evaluate the adhesion of P. acidilactici Kp10 to ileal mucosal epithelium. Samples of goat ileum, obtained immediately after slaughter from a local abattoir were washed in PBS to remove the ingesta from the mucosal surface. The samples were transported back to the laboratory in cooled PBS and incubated in cell suspension of $P$. acidilactici $\mathrm{Kp} 10\left(10^{9} \mathrm{CFU} / \mathrm{mL} \mathrm{PBS}\right)$ at $37^{\circ} \mathrm{C}$ for $30 \mathrm{~min}$. The samples were then prepared for scanning electron microscopy as described above.

\section{Auto-aggregation and co-aggregation assays}

The procedure as described by Polak-Berecka et al., [9] with some modifications was used to determine the 
specific cell-cell interactions using auto-aggregation and co-aggregation assays. Cells harvested at the stationary phase were collected by centrifugation $(5000 \times \mathrm{g}$ for $10 \mathrm{~min}$ at room temperature), washed twice and resuspended in PBS ( $\mathrm{pH}$ 7.2). For both assays, the culture suspension was standardized to OD $600 \mathrm{~nm}=1.0$ $\left(2 \times 10^{8} \mathrm{CFU} / \mathrm{mL}\right)$. For auto-aggregation assay, $5 \mathrm{~mL}$ of bacterial suspension was vortexed for $10 \mathrm{~s}$ and incubated at $37{ }^{\circ} \mathrm{C}$ for $2 \mathrm{~h}$. Absorbance of the supernatant was measured at $600 \mathrm{~nm}$ using a spectrophotometer (Perkin Elmer, Lambda 25, USA). The auto-aggregation coefficient (AC) was calculated according to Eq. 1 [10]:

$$
\mathrm{AC}_{\mathrm{t}}(\%)=\left[1-\left(\mathrm{OD}_{2 \mathrm{~h}} / \mathrm{OD}_{\mathrm{i}}\right)\right] \times 100
$$

where, $\mathrm{OD}_{\mathrm{i}}$ is the initial optical density of the microbial suspension at $600 \mathrm{~nm}$.

For the co-aggregation assay an equal volume $(2 \mathrm{~mL}$, $2 \times 10^{8} \mathrm{CFU} / \mathrm{mL}$ ) of $P$. acidilactici $\mathrm{Kp} 10$ and pathogenic bacterium (L. monocytogenes ATCC 15313) cultures were mixed, vortexed for $10 \mathrm{~s}$ and incubated at $37{ }^{\circ} \mathrm{C}$ for $2 \mathrm{~h}$. Each control tubes contained $4 \mathrm{~mL}$ of each bacterial suspension. The supernatants were measured at $\mathrm{OD}_{600} \mathrm{~nm}$ and co-aggregation was calculated according to Eq. 2 [11]:

$$
\text { Co-aggregation }(\%)=\left[1-\mathrm{OD}_{\text {mix }} /\left(\mathrm{OD}_{\text {strain }}+\mathrm{OD}_{\text {pathogen }}\right) / 2\right] \times 100
$$

where, $\mathrm{OD}_{\text {mix }}$ is the optical density of the mixture of $P$. acidilactici $\mathrm{Kp} 10$ and L. monocytogenes at $600 \mathrm{~nm}$, $\mathrm{OD}_{\text {strain }}$ is the optical density of $P$. acidilactici Kp10 at $600 \mathrm{~nm}$ and $\mathrm{OD}_{\text {pathogen }}$ is the optical density of L. monocytogenes at $600 \mathrm{~nm}$. Experiments were conducted in triplicates on two separate occasions.

\section{Adhesion of $P$. acidilactici Kp10 cell to solvents}

Adhesion of $P$. acidilactici Kp10 cell to solvents was assayed according to the method as described previously [12] with some modifications. Three tubes each containing $3 \mathrm{~mL}$ of $P$. acidilactici $\mathrm{Kp10}$ cell (grown in M17 broth at $37{ }^{\circ} \mathrm{C}$ for $18 \mathrm{~h}$ ) suspension in PBS (pH 7.2) at $10^{8} \mathrm{CFU} / \mathrm{mL}$, were each mixed with $1 \mathrm{~mL}$ of xylene, chloroform, ethylene acetate and n-hexadecane. The mixture was then vortexed for 1-2 min and allowed to stand for 5-10 min to allow separation of the mixture into two phases. The aqueous phase was measured at $600 \mathrm{~nm}$ using a spectrophotometer (Perkin Elmer, Lambda 25, USA). Bacterial affinities to solvents (BATS) with different physicochemical properties (hydrophobicity and electron donor-electron acceptor interactions) were expressed using Eq. 3:

$$
\operatorname{BATS}(\%)=\left(1-\mathrm{A}_{10 \min } / \mathrm{A}_{0 \min }\right) \times 100
$$

Where, $\mathrm{A}_{10 \mathrm{~min}}$ is the absorbance at $t=10 \mathrm{~min}$ and $\mathrm{A}_{0 \min }$ is the absorbance at $t=0 \mathrm{~min}$.
In a separate experiment, Congo red dye method was used to further investigate the cell surface hydrophobicity of $P$. acidilactici $\mathrm{Kp} 10$. Agar plates were initially prepared by mixing $2 \%(w / v) \mathrm{NaCl}$ in de Man, Rogosa and Sharpe (MRS) medium (Merck, Darmstadt, Germany), followed by the addition of sterile $0.03 \%(w / v)$ Congo red to the mixture. The bacterial strain was then crossstreaked and incubated at $37{ }^{\circ} \mathrm{C}$ for $24 \mathrm{~h}$. The colonies stained red were hydrophobic whereas the colorless colonies were considered as non-hydrophobic [13].

\section{Survivability studies on tolerance to phenol}

Study on the tolerance of P. acidilactici Kp10 to phenol was performed by inoculating the cultures in M17 broth with and without phenol. The samples $(100 \mu \mathrm{L})$ were then spread-plated onto MRS agar and incubated at $37^{\circ} \mathrm{C}$ for $24 \mathrm{~h}$. Bacterial survivability was enumerated using the formula as described previously [14].

\section{Transmission electron microscopy (TEM) for detection of the S-layer}

Cell suspensions of $P$. acidilactici Kp10 and Lactobacillus crispatus DSM 20584 (used as a control) were centrifuged at $5000 \times \mathrm{g}$ for $10 \mathrm{~min}$. The supernatants were pipetted and the pellets fixed in $2.5 \%$ glutaraldehyde in $0.1 \mathrm{M}$ sodium cacodylate buffer for 4 to $6 \mathrm{~h}$. The samples were then centrifuged and the supernatants pipetted to remove the fixative. A few drops of horse serum were added to each of the pellets. The coagulated pellets were then diced into $1 \mathrm{~mm}$ pieces. Following three washings with sodium cacodylate buffer the samples were post-fixed in $1 \%$ aqueous osmium tetroxide and dehydrated in ascending grades of acetone concentrations (30, 50, 75, 80, 95 and 100\%). Samples were then infiltrated overnight with an equal mixture (1:1) of resin and acetone. The samples were infiltrated with $100 \%$ resin in the following morning and dropped into resin-filled, pre-labeled BEEM capsules and polymerized at $60^{\circ} \mathrm{C}$ for $16 \mathrm{~h}$. Ultrathin sections on copper grids were stained with uranyl acetate and lead citrate and examined under the TEM. Cross sections of bacterial cells were examined to detect the S-layer in the cell wall of both strains.

\section{Haemolytic activity}

The haemolytic activity of $P$. acidilactici Kp10 was determined by growing the bacterial strain in M17 agar at $37{ }^{\circ} \mathrm{C}$ for $18 \mathrm{~h}$, and then streaked onto Columbia Agar plates containing $5 \% \mathrm{v} / \mathrm{v}$ of sheep blood (BioMeŕieux, Hazelwood, MO, USA). The plates were incubated at $37{ }^{\circ} \mathrm{C}$ overnight. Haemolytic reactions were recorded by the presence of a clear zone ( $\beta$-haemolysis), green zone $(\alpha$-haemolysis) or the absence of zone ( $\gamma$-haemolysis) around the colonies [15]. 
Determination of starter culture properties

Enzymatic characterization

API ZYM strips (API Identification Systems, bioMérieux, France), according to the manufacturer's instructions, were used to determine the enzymatic characteristics of $P$. acidilactici $\mathrm{Kp} 10$. The strips were incubated at $37{ }^{\circ} \mathrm{C}$ for $4 \mathrm{~h}$, and the reagents were then added. The color intensity was assessed according to the manufacturer's color chart. The test was performed in triplicates.

\section{Acidification and coagulation activities}

Effect of acidification and coagulation activities of $P$. acidilactici $\mathrm{Kp} 10$ was assayed by its inoculation into $10 \%$ skim milk at $1 \%$ level which incubated at $30{ }^{\circ} \mathrm{C}$. The activities were evaluated by observation for commencement of clotting followed by $\mathrm{pH}$ measurement after $72 \mathrm{~h}$ [16].

\section{Qualitative proteolytic activity and starch hydrolysis}

$P$. acidilactici Kp10 culture was streaked on M17 agar for 24-48 h. Heavy inoculum of the culture was then streaked on skim milk agar and M17-starch agar and incubated at $37{ }^{\circ} \mathrm{C}$ for $24-48 \mathrm{~h}$. Clear zone surrounding colonies on skim milk agar indicated proteolytic activity. To detect the hydrolysis of starch, M17-starch agar was topped with iodine solution [17]. L. monocytogenes ATCC 15313 and E. coli ATCC 25922 were used as negative controls.

\section{Results and discussion}

The inhibitory activity of the probiotic strain plays an important role in competing with other microorganisms in the gastrointestinal tract (GIT) protecting the latter from being colonized by food-borne pathogens. The inhibitory spectra of $P$. acidilactici Kp10 against different gram-positive and gram-negative bacteria in the present study showed an antagonistic effect of the growth of gram-positive and gram-negative pathogenic microorganisms. The potential probiotic bacterial strain in this study demonstrated an inhibitory activity against $L$. monocytogenes ATCC 15313, S. enterica ATCC 13311, Sh. sonnei ATCC 9290, K. oxytoca ATCC 13182, E. cloaca ATCC 35030, St. pyogenes ATCC 12378 (Table 1). There was significant difference $(P<0.05)$ between the inhibitory spectrum of $P$. acidilactici $\mathrm{Kp} 10$ against $L$. monocytogenes 15313 and five other strains while no significant differences $(P>0.05)$ was observed in inhibitory spectrum of Kp10 against these five strains. To date there are limited reports concerning the inhibitory effects of LAB on gram-negative bacteria due to the structure of their bacterial cell envelopes which is much more complex compared to that of gram-positive bacteria [18]. Their resistance to many antimicrobial agents is attributed to an effective permeable barrier of lipopolysaccharide layer of the outer membrane.
Table 1 Inhibitory spectrum of $P$. acidilactici Kp10 against grampositive and gram-negative bacteria

\begin{tabular}{ll}
\hline Microorganism & $\begin{array}{l}\text { Zone diameter } \\
(\mathrm{mm})\end{array}$ \\
\hline L. monocytgenes ATCC 15313 & $21 \pm 0.1^{\mathrm{a}}$ \\
S. enterica ATCC 13311 & $11 \pm 0.05^{\mathrm{b}}$ \\
Sh. sonnei ATCC 9290 & $11 \pm 0.8^{\mathrm{b}}$ \\
K. oxytoca ATCC 13182 & $11 \pm 0.03^{\mathrm{b}}$ \\
E. cloaca ATCC 35030 & $11 \pm 0.5^{\mathrm{b}}$ \\
S. pyogenes ATCC 12384 & $11 \pm 0.7^{\mathrm{b}}$ \\
P. acidilactici Kp10 & 0 \\
\hline
\end{tabular}

Data are mean values \pm SD $(n=3)$

Values with different superscript letters ( $a$ and $b$ ) are significantly different $(P<0.05)$

P. acidilacticiKp10 inhibited the growth of L. monocytogenes which is an important food-borne pathogen (Fig. 1). This observation could infer that $P$. acidilactici Kp10 has the potential to be used as a probiotic microorganism to overcome some major challenges facing the food industry and regulatory agencies. In addition, Kp10 was resistant to its own BLIS as indicated by the absence of activity around the well (Fig. 1). All bacteriocin producing isolates could protect themselves from the adverse effect of their own bacteriocins by the production of an immune protein commonly linked to the C-terminal domain of the bacteriocin [19]. Our finding is in agreement with the earlier reports which stated that bacteriocin producer could protect itself from the adverse effect of its own antimicrobial compounds by a defense system which is expressed concomitantly with the antimicrobial peptide(s) [20, 21]. Some bacteriocinogenic strains have no receptors which would then absorb their own bacteriocins thus rendering the bacteriocin ineffective against their own producer strain. Bacteriocin action and bacteriocin resistance were demonstrated to be contributed by the cell wall as well as its membrane lipid composition. As shown in Fig. 1, two zones of inhibition were observed. During the initial phase of incubation there was high antimicrobial activity which was demonstrated by an inner clear zone. During incubation there was an accompanying increase in $\mathrm{pH}$ of the substrate whence the antimicrobial range of activity was approaching its optimum. The antimicrobials further inhibit the growth of the microorganism in the area of the peripheral zone where the concentration of antimicrobials are lower than that presence in the central area [22]. However, it could be result of the presence of more than one bacteriocin.

Adhesion of P. acidilactici Kp10 to Vero cells and goat ileum mucosal epithelium as observed under the scanning electron microscope (SEM) are shown in Fig. 2a and $\mathrm{b}$. To our knowledge previous reports on the adhesion of LAB were tested in rats intestine [23], columnar epithelial cells of pigs and calves [8] and ileum of 


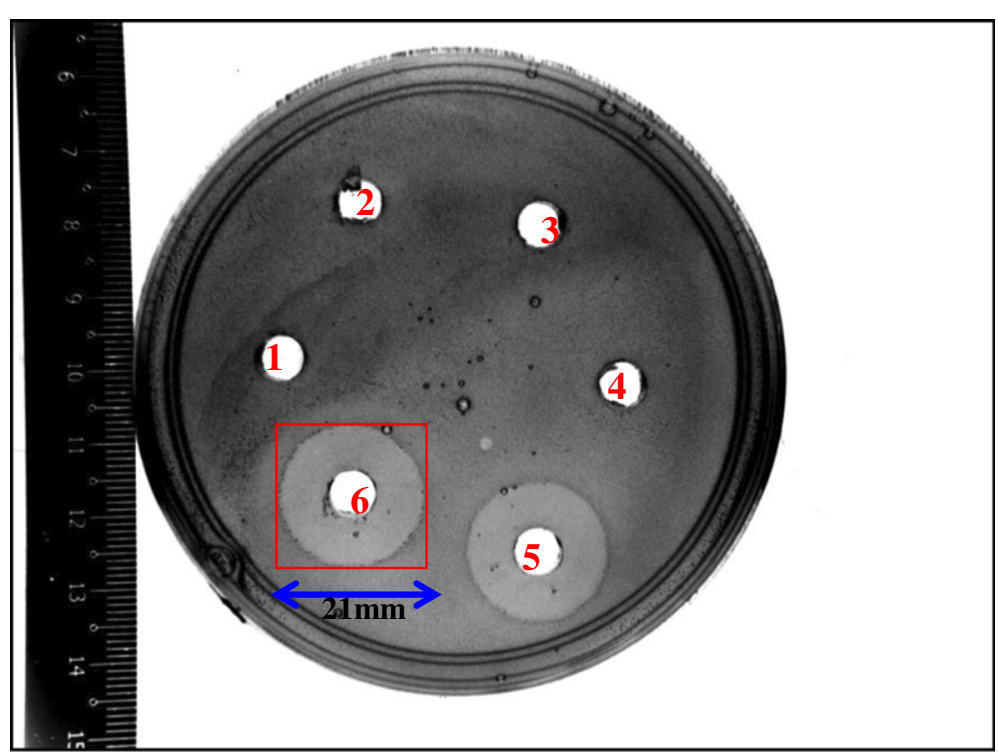

Fig. 1 Antimicrobial activity of $P$. acidilactici Kp10 against L. monocytogenes ATCC 15313 determined by agar well diffusion method (1 and 2: water; 3 and 4: media; 5 and 6: CFCS of P. acidilactici Kp10)

Landrace pigs [10]. The objective of this part of our study was to test qualitatively the colonization of LAB onto epithelial cells. As probiotic could be used in both human and animals we therefore examined LAB colonization in an animal species which have not been previously reported and in this case the goat. Human epithelial cells were not used as these cells were not easily available from our perspective. The goat being a ruminant is thus a species which is most remotely related to the human; however surprisingly our results demonstrated that $\mathrm{LAB}$ are capable of colonizing the goat epithelium which further augment our claim that $P$. acidilactici $\mathrm{Kp} 10$ is applicable to both human and animals. Colonization with extended transit time is most critical for optimal expression of general and specific physiological functions of probiotic microorganisms. Probiotic strains invariably should demonstrate the ability to adhere to the surface mucosal epithelial cells, an important requirement with reference to effective colonization [24]. Cell adhesion which involve contact between the cell membrane of the bacteria and that of the mucosal epithelium is no doubt a complex process. There were a number of constrains in the evaluation of bacterial adhesion capability in vivo especially in humans. These constrains had prompted a number in vitro studies to be undertaken instead which were directed towards screening bacterial strains with adhering potentials.

For the beneficial effect of probiotics to manifest, there is a need to achieve an adequate mass through aggregation. In a number of ecological niches auto-aggregation, which are cell aggregation between microorganisms of similar strain or co-aggregation, aggregation of genetically different strain, are of considerable importance [25]. LAB with aggregation ability and hydrophobicity cell surface could be more capable to adhere to intestinal epithelial cells. It has been reported that some LAB can prevent
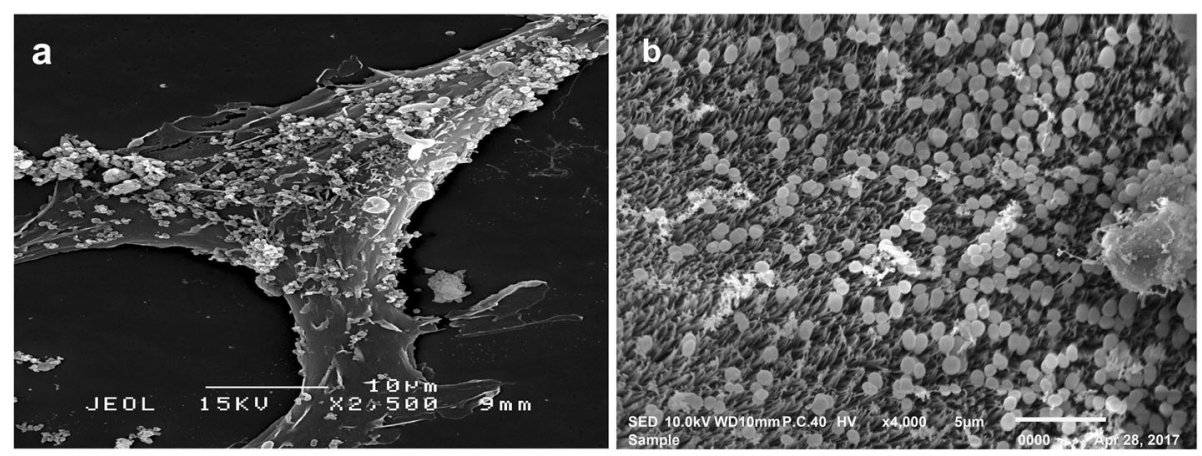

Fig. 2 SEM showing adhesion of $P$. acidilactici Kp10 to the surface of: a Vero cells, and $\mathbf{b}$ mucosal epithelium of goat ileum 
adherence of pathogens to intestinal mucosa either by forming a barrier via auto-aggregation or by coaggregation with the pathogens [26-28]. Invariably cell adherence properties are aggregation ability related.

Auto-aggregation of probiotics appeared to be necessary for the adhesion to intestinal epithelial cells. In addition, the ability to co-aggregate with pathogens may form a barrier which prevents colonization by pathogens. Adherence of bacterial cells is usually related to cell surface characteristics $[29,30]$. Hydrophobicity, one of cell surface physicochemical characteristics could affect auto-aggregation and adhesion of bacteria to different surfaces [25]. It was reported that auto-aggregation of LAB is associated with their adhesion ability [28].

The co-aggregation ability could allow LAB strains to inhibit the growth of pathogens in the gastrointestinal and urogenital tracts [31]. Furthermore, LAB strains have a major influence on the micro-environment around the pathogens and in the process of co-aggregation increase the concentration of antimicrobial substances secreted [26, 32]. Additionally, co-aggregation of inhibitor-producing LAB with the pathogens could possibly constitute an important host defense mechanism in the urogenital and GIT. The ability of LAB to co-aggregate with gut pathogens could potentially be a probiotic property of the microorganism [25].

Thus, the potential of $P$. acidilactici $\mathrm{Kp} 10$ as a probiotic strain was evaluated for its auto-aggregation and coaggregation ability with a foodborne pathogenic bacterium, L. monocytogenes. P. acidilactici $\mathrm{Kp} 10$ had higher auto-aggregation values (35.2\%) compared to that of $L$. monocytogenes ATCC 15313 (24.7\%). P. acidilactici Kp10 had a co-aggregation ability with $L$. monocytogenes ATCC 15313 of about $46 \%$ (Table 2). Our results concurred with that reported previously [11] for $P$. acidilactici KACC 12307 which had auto-aggregation and co-aggregation values of 35.2 and $46 \%$, respectively. It was also reported that probiotics had higher auto-aggregation abilities than the pathogens [26, 33].

Cell surface hydrophobicity is another physicochemical property that facilitates first contact between

Table 2 Aggregation abilities of P. acidilactici Kp10 and $L$. monocytogenes ATCC 15313

\begin{tabular}{|c|c|c|}
\hline & P. acidilactici Kp10 & $\begin{array}{l}\text { L. monocytogenes } \\
\text { ATCC } 15313\end{array}$ \\
\hline \multirow[t]{2}{*}{ Auto-aggregation (\%) } & $35.2 \pm 0.07^{a}$ & $24.7 \pm 0.1^{b}$ \\
\hline & $\begin{array}{l}\text { P. acidilactici Kp10 with } \\
\text { L. monocytogenes } \\
\text { ATCC } 15313\end{array}$ & \\
\hline Co-aggregation (\%) & $46 \pm 0.6$ & \\
\hline
\end{tabular}

Mean ( \pm standard deviation) of results from three separate experiments Values with different superscript letters ( $a$ and $b$ ) are significantly different $(P<0.05)$ microorganisms and host cells. This non-specific initial interaction is weak and reversible and precedes the subsequent adhesion process mediated by more specific mechanisms involving cell-surface proteins and lipoteichoic acids [34-36]. Thus the contribution of hydrophobicity to adhesion capacity could probably be due to the lack of correlation between hydrophobicity and bacterial adhesion [37-39].

Affinity for chloroform, an acidic and monopolar solvent, reflected the reducing (alkalic) nature of the bacterium. However, its affinity to ethylacetate, an alkalic and monopolar solvent, reflected the oxidizing (acidic) nature of the bacterium. Furthermore, affinity towards apolar solvents (hexadecane and xylene) demonstrated the hydrophobic nature of the bacterium. High hydrophobicity is linked to glycoproteins on the bacterial surface while low hydrophobicity is linked to the presence of polysaccharides on the bacterial surface [40].

The adhesion ability of $P$. acidilactici Kp10 to four different solvents (chloroform, xylene, ethylacetate and nhexadecane) are summarized in Table 3. P. acidilactici Kp10 has a strong affinity (46.97\%) for xylene, indicating the cells were hydrophobic. The Lewis acid-base characteristics of the cell surface of P. acidilactici Kp10 was assessed by its adhesion to chloroform and ethyl acetate. The results showed that $P$. acidilactici $\mathrm{Kp} 10$ had a stronger/higher affinity to chloroform (12.42\%), an acidic solvent and electron acceptor compared to that of ethyl acetate $(5.67 \%)$ a basic solvent and electron donor. $P$. acidilactici Kp10 showed a low hydrophobicity (14.55\%) for $n$-hexadecane and positive to Congo red by the presence of red colonies on the agar plate, indicating that it has the hydrophobic structures in its cell wall (Fig. 3).

Some aromatic amino acids derived from dietary or endogenously produced proteins that can be deaminated by gut bacteria leading to the formation of phenolic compounds [41]. These compounds exert a bacteriostatic effect against some bacterial strains. The survivability test of probiotics in the intestine refers to their resistance to $0.4 \%$ phenol, a catabolic product of aromatic amino acids with bacteriostatic activity [14]. The tolerance of P. acidilactici Kp10 to phenol for $24 \mathrm{~h}$ is shown in Table 4 . Growth of the bacterium was not markedly inhibited as the bacterial strain could still grow in the presence of $0.1 \%$ phenol during the incubation.

Table 3 Adhesion of $P$. acidilactici Kp10 to xylene, chloroform, ethyl acetate and $\mathrm{n}$ - hexadecane

\begin{tabular}{lllll}
\hline Solvent & Xylene & Chloroform & Ethyl acetate & $\mathrm{n}$ - hexadecane \\
\hline $\begin{array}{l}\text { Adhesion } \\
(\%)\end{array}$ & $46.97 \pm 0.01^{\mathrm{a}}$ & $12.42 \pm 0.01^{\mathrm{c}}$ & $5.67 \pm 0.04^{\mathrm{d}}$ & $14.55 \% \pm 0.1^{\mathrm{b}}$
\end{tabular}

Mean ( \pm standard deviation) of results from three separate experiments Values with different superscript letters $(a, b, c, d)$ are significantly different $(P<0.05)$ 


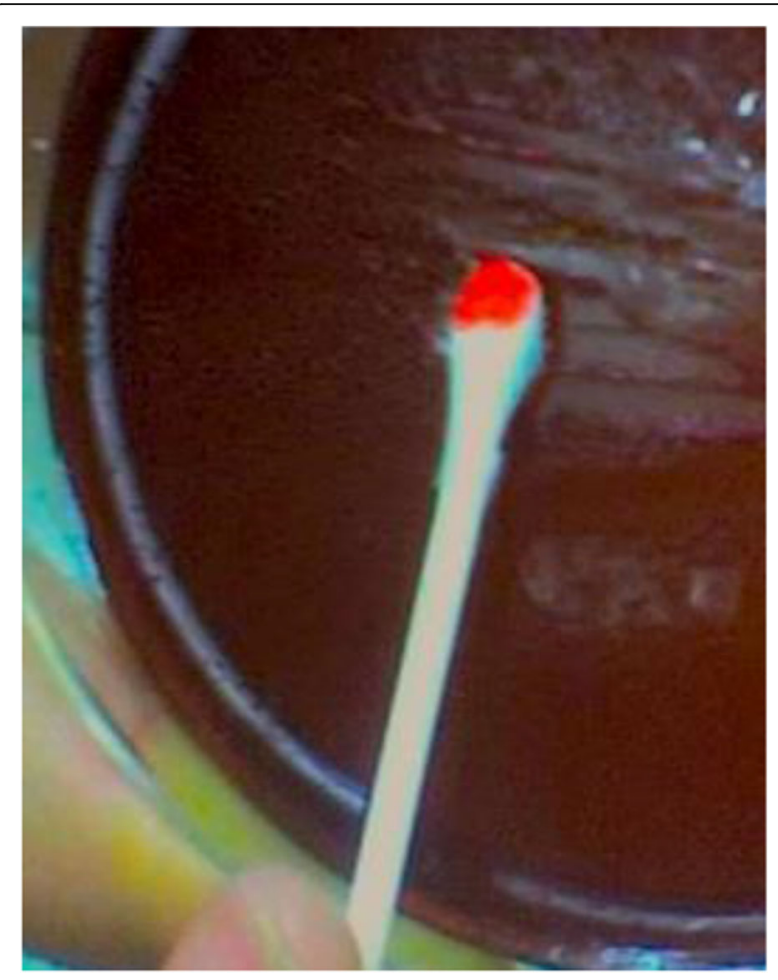

Fig. 3 Cell surface hydrophobicity of P. acidilactici Kp10 with Congo red dye

Results showed that $P$. acidilactici Kp10 was moderately tolerant to phenol. A similar result was also reported for Lb. plantarum Lp-115 [28]. Bacteria that are tolerant to phenols may have better chances of survival in the GIT. Some LAB strains such as Lb. acidophilus DC601, Lb. gasseri $\mathrm{BO} 3$, Lb. paracasei $\mathrm{BO} 52$ are tolerant to high phenol concentrations (0.4 to $0.5 \%)$ [14, 42], although the physiology of these bacteria are closely related to $P$. acidilactici Kp10.

Transmission electron micrographs of the $P$. acidilactici Kp10 and Lb. crispatus DSM 20584 (DSM: Deutsche Sammlung von Mikroorganismen un Zellkulturen $\mathrm{GmbH}$ /Braunschweig, Germany) are shown in Fig. 4a and b, respectively. From the micrographs, it can be seen that S-layers were presence in the cell wall of both strains. In

Table 4 Tolerance of $P$. acidilactici Kp10 cells to phenol

\begin{tabular}{llll}
\hline M17+ \% of phenol & \multicolumn{3}{l}{ Viable counts ${ }^{\mathrm{a}}\left(\mathrm{Log}_{10} \mathrm{CFU} / \mathrm{mL}\right)$} \\
\cline { 2 - 4 } & $\mathrm{T}_{0}$ & $\mathrm{~T}_{24}$ & Inhibition $^{\mathrm{b}}$ \\
\hline Blank (without phenol) & $5.09 \pm 0.01$ & $7.56 \pm 0.0$ & -2.47 \\
0.1 & $5.04 \pm 0.0$ & $6.47 \pm 0.0$ & -1.43 \\
0.2 & $5.04 \pm 0.15$ & $4.75 \pm 0.13$ & 0.29 \\
0.3 & $5.06 \pm 0.06$ & $4.11 \pm 0.08$ & 0.95 \\
0.4 & $5.07 \pm 0.25$ & $3.48 \pm 0.0$ & 1.59
\end{tabular}

${ }^{a}$ Log mean counts of three trials (mean \pm S.E)

${ }^{\mathrm{b}}$ Inhibition $=\log _{10}($ initial population $)-\log _{10}($ final population $)$
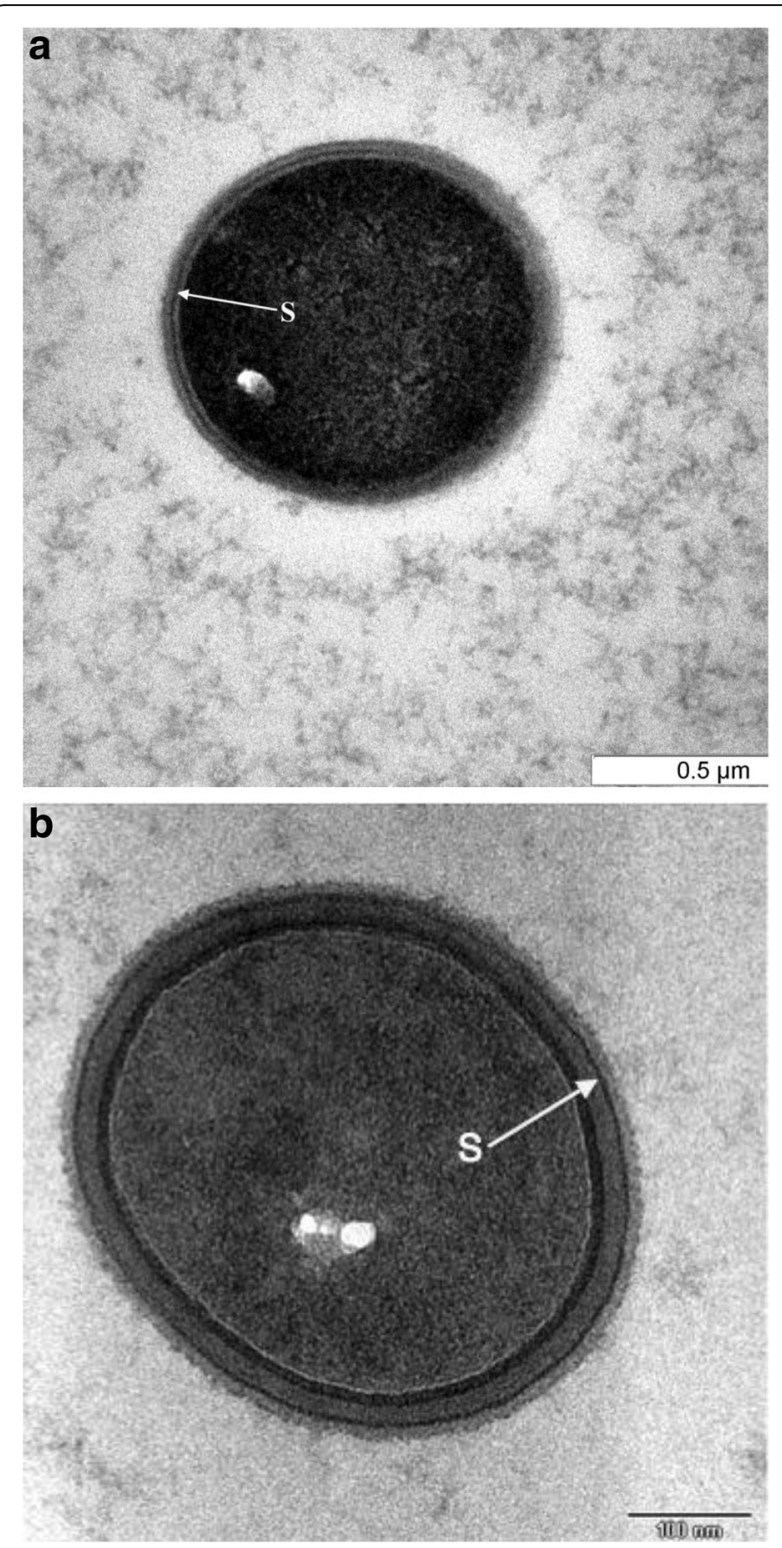

Fig. 4 TEM of a cross-section of (a) P. acidilactici Kp10 and (b) Lb. crispatus DSM 20584 cells showing the S-layer (arrow) in the cell wall of the bacterium

P. acidilactici Kp10, the S-layer was located in the middle of the thick cell wall. However, the S-layer of Lb. crispatus DSM 20584 was located more superficially in the bacterial cell wall. S-layer or crystalline surface layer is a common feature of eubacteria and archaebacteria [43]. The structure is composed of identical subunits consisting of a single protein species linked to each other as well as to the supporting cell wall, also known as specific hydrophobic cell surface proteins [44]. The biological functions of the S-layer in eubacteria include protection, cell adhesion and surface recognition [45]. The S-layer protein from $L b$. crispatus JCM 5810 was also involved in adhesion [46] and 
the inhibition of adhesion of $E$. coli to the basement membrane of mucosal epithelium [47]. With reference to the function of the S-layer it could be a contributing factor in the adhesion of $P$. acidilactici Kp10 to Vero cells and the intestinal mucosa of goat ileum as observed in the present study. A more conclusive identification of this structure could be obtained by generating an antibody against the specific hydrophobic cell surface protein and gold-labeling the antibody [48].

The absence of pathogenicity traits such as the absence of haemolytic activity in cultures, as observed in this study, suggested the suitability of application of $P$. acidilactici Kp10 in foods [49]. The absence of haemolytic activity is considered a safety prerequisite for the selection of a probiotic strain [50]. P. acidilactici Kp10 exhibited $\gamma$ haemolytic activity (no haemolysis) when grown in Columbia blood agar. Similar observations were reported in Lb. paracasei subsp. paracasei, Lactobacillus spp. and $L b$. casei isolated from dairy products which showed $\gamma$ haemolysis except of few that showed $\alpha$-haemolysis [51]. Most of the LAB strains ( 69 from 71 strains) have been reported as $\gamma$-haemolytic (i.e. no haemolysis) [52].

Application of the commercial API-ZYM is for the selection of strains as potential starter cultures based on superior enzyme profiles especially peptidases and esterases. The test system is also applicable in the determining accelerated maturation and flavor development of fermented products [53]. Esterase in particular from $\mathrm{LAB}$ may be involved in the development of fruity flavors and quality improvement in dairy and meat products such as cheese, cured bacon and fermented sausages [54]. Enzymatic activities of P. acidilactici Kp10 as evaluated by the semi-quantitative API-ZYM system is shown in Table 5. P. acidilactici $\mathrm{Kp} 10$ exhibited a very low level of alkaline phosphatase, a lipolytic enzyme. Kp10 demonstrated strong peptidase (leucine-arylamidase) and esterase-lipase (C4 and C8) activities. Proteinases (trypsin) activity is however absent in Kp10. The above are two possible desirable traits for the production of typical flavor. Similar results have been reported on the use of LAB as a starter culture and potential technological implications by increasing desirable flavor in seafood products [55-57].

Acidification is an important technological and functional property in the selection of LAB as a starter culture [58]. It was found that $P$. acidilactici $\mathrm{Kp} 10$ acidified the skim milk used by lowering the $\mathrm{pH}$ to 5.3 apart from showing strong coagulating activities. The potential of LAB strains for application as a starter or adjunct cultures in the production of fermented products is demonstrated by their ability to coagulate milk. Results showed that $P$. acidilactici Kp10 exhibited proteolytic activity which is in agreement with the reports published by [59] and [60] for other LAB. LAB are weakly proteolytic
Table 5 Enzyme activities of P. acidilactici Kp10

\begin{tabular}{|c|c|c|}
\hline & Enzyme & Production \\
\hline 1 & Control & - \\
\hline 2 & Alkalinephosphatase & + \\
\hline 3 & Esterase (C4) & ++ \\
\hline 4 & Esteraselipase (C8) & ++ \\
\hline 5 & Lipase (C14) & - \\
\hline 6 & Leucinearylamidas & ++ \\
\hline 7 & Valinearylamidase & - \\
\hline 8 & Cystinearylamidas & - \\
\hline 9 & Trypsin & - \\
\hline 10 & a-chymotrypsin & ++++ \\
\hline 11 & Acidphosphatase & + \\
\hline 12 & Naphthol-AS-Bl-phosphohydrolase & ++ \\
\hline 13 & a-galactosidase & ++++ \\
\hline 14 & $\beta$-galactosidase & ++++ \\
\hline 15 & $\beta$-glucuronidase & - \\
\hline 16 & a-glucosidase & ++++ \\
\hline 17 & $\beta$-glucosidase & ++++ \\
\hline 18 & N-acetyl-b-glucosaminidase & - \\
\hline 19 & a-mannosidase & - \\
\hline 20 & a-fucosidase & - \\
\hline
\end{tabular}

' + ' refers to positive reaction; '-' refers to negative reaction

compared with other groups of bacteria such as Bacillus, Proteus, Pseudomonas and Coliforms [61] but the bacterial strains do cause a significant degree of proteolysis in many fermented dairy products [62]. LAB is capable of hydrolyzing oligopeptides into small peptides and amino acids as it possess a very comprehensive proteinase/peptidase system [63]. Many dairy starter cultures are proteolytic thus bioactive peptides can be generated and used in the manufacturing of fermented dairy products. To prepare an experimental starter the technological properties of LAB should include growth, acidifying, proteolytic and amylolytic activities [64].

P. acidilactici Kp10 showed positive results for amylolactic activity. Amylases produced by amylolytic LAB (ALAB) facilitate hydrolysis and fermentation of starch to lactic acid in a single step process [65]. ALAB can thus be utilized in commercial production of lactic acid from starchy materials and in reducing the viscosity of starchy complementary foods $[66,67]$. Apart from altering the microstructure of starch, ALAB could also modify the amylography and viscosity of starch. $\alpha$-amylases of ALAB has the ability of partially hydrolyzing raw starch and as such this microorganism could ferment different types of amylaceous raw materials viz. wheat, potato and different starchy substrates [68]. Taking into consideration the global importance and availability of starchy biomass, production of amylases and lactic acid 
from starch present two potential industrial applications of ALAB. Bulk production of amylases through microbial fermentation could beneficially be utilized in starch degradation which could supply $25-33 \%$ of the global enzyme market [69]. Direct conversion of starchy materials to lactic acid by LAB with ability in secreting amylolytic enzymes in a single-step production process is preferred at industrial scale. This approach will eliminate the two-step process, which include enzymatic saccharification for stach hydrolysis followed with LAB fermentation to convert sugar to lactic acid, Production cost could be substantially reduced with a sing-step process to ensure it is economically viable.

\section{Conclusion}

Results from the present study provided ample evidences to claim that $P$. acidilactici $\mathrm{Kp} 10$ is a potential probiotic and starter culture. However the data generated were based purely on in vitro studies. In order to claim that this microorganism is categorically a probiotic strain, the survivability and ability to express its probiotic potential in the gastrointestinal environment is also the important criterion to be considered. The environment in the gastrointestinal tract is not only different from that of in vitro, there are also a number of the interacting factors that have major influences on the survivability and its probiotic characteristics. The robust environment at industrial scale may not be favourable to the performance and the capability of the selected probiotic strain. To support the recommendation of using P. acidilactici Kp10 in food industry, a comprehensive study to identify their comparative advantages is required. However, this is not the objective of this paper. The results obtained from the present in vitro studies gave ample evidences to indicate that $P$. acidilactici Kp10 is a promising probiotic and starter culture potential. However a comprehensive in vivo investigations are required to categorically substantiate its true potential.

\section{Abbreviations}

AC: Auto-aggregation coefficient; ALAB: Amylolytic LAB; BATS: Bacterial cell adhesion to solvent; BLIS: Bacteriocin-like inhibitory substances; DMEM: Dulbecco's modified eagle medium; GIT: Gastrointestinal tract; LAB: Lactic acid bacteria; MRS: de Man, Rogosa and Sharpe; OD: Optical density; PBS: Phosphate-buffered saline; RPMl: Roswell park memorial institute medium; SEM: Scanning electron microscope; TEM: Transmission electron microscope

\section{Acknowledgement}

The authors wish to specifically thank to Prof. Dr. Abdul Rahman Omar, Laboratory of Vaccine and Therapeutics, Institute of Bioscience, University Putra Malaysia for his contribution on the use of cell lines in this study.

\section{Funding}

This study was financially supported by research fund from the Ministry of Higher Education Malaysia under Prototype Research Grant Scheme (PRGS) and the reference number is PRGS/2/2015/SG05/UPM/01/2.

\section{Availability of data and materials}

$16 S$ rRNA gene sequences supporting the results of this article are available in the GenBank Database (https://www.ncbi.nlm.nih.gov/genbank/) under the accession number JN592051.

\section{Authors' contributions}

SA participated in the project conception, carried out all the experimental work, analyzed and interpreted the data and wrote the manuscript. ABA was corresponding author, designed and supervised the entire project. All authors contributed to the design and interpretation of experimental results, as well as editing and revising the manuscript. All authors have read and approved the final manuscript.

\section{Competing interests}

The authors declare that they have no competing interests.

\section{Consent for publication}

Not applicable.

\section{Ethics approval and consent to participate}

The study did not involve the use of laboratory animals; hence ethics approval is not applicable in this manuscript. The cell lines used in this study were kindly donated by Laboratory of Vaccine and Therapeutics, Institute of Bioscience, University Putra Malaysia as indicated above. The goat tissue used in this study was obtained from the abattoir and a blanket cover is given whenever materials are required by the university.

\section{Publisher's Note}

Springer Nature remains neutral with regard to jurisdictional claims in published maps and institutional affiliations.

\section{Author details}

'Department of Microbiology, Faculty of Biotechnology and Biomolecular Sciences, Universiti Putra Malaysia, 43400 UPM Serdang, Selangor, Malaysia. ${ }^{2}$ Bioprocessing and Biomanufacturing Research Centre, Faculty of Biotechnology and Biomolecular Sciences, Universiti Putra Malaysia, 43400 UPM Serdang, Selangor, Malaysia. ${ }^{3}$ School of Industrial Technology, Universiti Sains Malaysia, 11800 George Town, Penang, Malaysia. Institute of Bioscience, Universiti Putra Malaysia, 43300 Serdang, Selangor, Malaysia. ${ }^{5}$ Faculty of Veterinary Medicine, Universiti Putra Malaysia, 43400 UPM Serdang, Selangor, Malaysia.

Received: 18 October 2016 Accepted: 4 April 2017

Published online: 23 May 2017

\section{References}

1. Abbasiliasi S, Joo Shun T, Ibrahim TAT, Ramanan RN, Vakhshiteh F, Mustafa S. Isolation of Pediococcus acidilactici Kp10 with ability to secrete bacteriocin-like inhibitory substance from milk products for applications in food industry. BMC Microbiol. 2012;12(1):260.

2. Rhee $\mathrm{SJ}$, Lee JE, Lee $\mathrm{CH}$. Importance of lactic acid bacteria in Asian fermented foods. Microb Cell Factories. 2011;10:55-68.

3. Visessanguan W, Benjakul S, Smitinont T, Kittikun C, Thepkasikul P, Panya A. Changes in micro- biological, biochemical and physico-chemical properties of nham inoculated with different inoculum levels of Lactobacillus curvatus. LWT-Food Sci Technol. 2006;39:814-26.

4. Quarantelli A, Righi F, Agazzi A, Invernizzi G, Ferroni M, Chevaux E. Effects of the administration of Pediococcus acidilactici to laying hens on productive performance. Vet Res Commun. 2008;32:359-61.

5. Guerra NP, Bernárdez PF, Méndez J, Cachaldora P, Pastrana Castro L. Production of four potentially probiotic lactic acid bacteria and their evaluation as feed additives for weaned piglets. Animal Feed Sci Technol. 2007;134(1):89-107.

6. Abbasiliasi S, Tan J, Kadkhodaei S, Nelofer R, Tengku Ibrahim TA, Mustafa S, Ariff AB. Enhancement of BLIS production by Pediococcus acidilactici kp10 in optimized fermentation conditions using an artificial neural network. RSC Adv. 2016;6(8):6342-9.

7. Gopal PK, Prasad J, Smart J, Gill HS. In vitro adherence properties of Lactobacillus rhamnosus DR20 and Bifidobacterium lactis DR10 strains and their antagonistic activity against an enterotoxigenic Escherichia coli. Int J Food Microbiol. 2001;67(3):207-16. 
8. Mäyrä-Mäkinen A, Manninen M, Gyllenberg $H$. The adherence of lactic acid bacteria to the columnar epithelial cells of pigs and calves. J Appl Microbiol. 1983;55:241-5

9. Polak-Berecka M, Waśko A, Paduch R, Skrzypek T, Sroka-Bartnicka A. The effect of cell surface components on adhesion ability of Lactobacillus rhamnosus. Antonie Van Leeuwenhoek 2014, 106:751-762.

10. Kos B, Suskovic J, Vukovic S, Simpraga M, Frece J, Matosic S. Adhesion and aggregation ability of probiotic strain Lactobacillus acidophilus M92. J Appl Microbiol. 2003;94(6):981-7.

11. $\mathrm{Xu} \mathrm{H}$, Jeong HS, Lee HY, Ahn J. Assessment of cell surface properties and adhesion potential of selected probiotic strains. Lett Appl Microbiol. 2009; 49(4):434-42.

12. Beena AK, Anupa A. A study on the probiotic aspects of Lactobacillus isolated from raw milk of Vechur. Int J Sci Res. 2015;4(12):192-3.

13. Sharma KK, Soni SS, Meharchandani S. Congo red dye agar test as an indicator test for detection of invasive bovine Escherichia coli. Veterinarski Arhiv. 2006; 76(4):363-6.

14. Xanthopoulos V, Litopoulou-Tzanetaki E, Tzanetakis N. Characterization of Lactobacillus isolates from infant faeces as dietary adjuncts. Food Microbiol. 2000;17(2):205-15.

15. De Vuyst L, Foulquie Moreno MR, Revets H. Screening for enterocins and detection of hemolysin and vancomycin resistance in enterococci of different origins. Int J Food Microbiol. 2003;84:299-318.

16. Chettri R, Tamang JP. Functional properties of tungrymbai and bekang, naturally fermented soybean foods of North East India. Int J Fermented Foods. 2014;3:87-103.

17. Pailin T, Kang DH, Schmidt K, Fung DYC. Detection of extracellular bound proteinase in EPS-producing lactic acid bacteria cultures on skim milk agar. J Appl Microbiol. 2001;133:45-9.

18. Chung $\mathrm{H}-\mathrm{J}$. Control of foodborne pathogens by bacteriocin-like substances from Lactobacillus spp. in combination with high pressure processing. USA: The Ohio State University; 2003.

19. Bharti $V$, Mehta A, Singh S, Jain N, Ahirwal L, Mehta S. Bacteriocin: A novel approach for preservation of food. Int J Pharm Pharm Sci. 2015;17(9):20-9.

20. oglu Gulahmadov SG, Batdorj B, Dalgalarrondo M, Chobert JM, oglu Kuliev AA, Haertlé T. Characterization of bacteriocin-like inhibitory substances (BLIS) from lactic acid bacteria isolated from traditional Azerbaijani cheeses. Euro Food Res Technol. 2006;224(2):229-35.

21. Koponen O. Studies of producer self-protection and nisin biosynthesis of Lactococcus lactis. Helsinki: University of Helsinki; 2004.

22. Korkeala H, Pekkanen TJ. The testing of the antibiotic sensitivity of bacteria on an agar medium: the problem of a double zone of inhibition. Acta Path Micro Im B. 1977:85:174-6.

23. Anggraeni $\mathrm{D}$. Attachment study of lactic acid bacteria originated from human breast milk. Bogor: Bogor Agricultural University; 2010.

24. Duary RK, Rajput YS, Batish VK, Grover S. Assessing the adhesion of putative indigenous probiotic lactobacilli to human colonic epithelial cells. Ind J Medic Res. 2011;134(5):664.

25. Balakrishna A. In vitro Evaluation of Adhesion and Aggregation Abilities of Four Potential Probiotic Strains Isolated from Guppy (Poecilia reticulata). Braz Arch Biol Technol. 2013:56:793-800

26. Li Q, Liu X, Dong M, Zhou J, Wang Y. Aggregation and adhesion abilities of 18 lactic acid bacteria strains isolated from traditional fermented f ood. Int J Agri Policy Res. 2015;3:84-92.

27. Vlková E, Rada V, Smehilova M, Killer J. Auto- aggregation and co-aggregation ability in bifidobacteria and clostridia. Folia Microbiol. 2008;53:263-9.

28. Collado MC, Meriluoto J, Salminen S. Adhesion and aggregation properties of probiotic and pathogen strains. Eur Food Res Technol. 2008;226:1065-73.

29. Bibiloni R, Perez PF, Garrote GL, Disalvo EA, De Antoni GL. Surface characterization and adhesive properties of bifidobacteria. Method Enzymol. 2001;336:411-27.

30. Canzi E, Guglielmetti S, Mora D, Tamagnini T, Parini C. Conditions affecting cell surface properties of human intestinal bifidobacteria. Antonie Van Leeuwenhoek. 2005;88:207-19.

31. Botes M, Loos B, van Reenen CA, Dicks LM. Adhesion of the probiotic strains Enterococcus mundtii ST4SA and Lactobacillus plantarum 423 to Caco-2 cells under conditions simulating the intestinal tract, and in the presence of antibiotics and anti-inflammatory medicaments. Arch Microbiol. 2008;190:573-84

32. Kaewnopparat S, Dangmanee N, Kaewnopparat N, Srichana T, Chulasiri M, Settharaksa S. In vitro probiotic properties of Lactobacillus fermentum SK5 isolated from vagina of a healthy woman. Anaerobe. 2013;22:6-13.
33. Pan X, Chen F, Wu T, Tang H, Zhao Z. The acid, bile tolerance and antimicrobial property of Lactobacillus acidophilus NIT. Food Control. 2009;20:598-602.

34. Granato D, Perotti F, Masserey I, Rouvet M, Golliard M, Servin A. Cell surfaceassociated lipoteichoic acid acts as an adhesion factor for attachment of Lactobacillus johnsonii La1 to human enterocyte-like Caco-2 cells. Appl Environ Microbiol. 1999;65(3):1071-7.

35. Rojas M, Ascencio F, Conway PL. Purification and characterization of a surface protein from Lactobacillus fermentum 104R that binds to porcine small intestinal mucus and gastric mucin. Appl Environ Microbiol. 2002; 68(5):2330-6.

36. Roos $\mathrm{S}$, Jonsson $\mathrm{H}$. A high-molecular-mass cell-surface protein from Lactobacillus reuteri 1063 adheres to mucus components. Microbiol. 2002;148(2):433-42.

37. Kim HJ, Camilleri M, McKinzie S, Lempke MB, Burton DD, Thomforde GM. A randomized controlled trial of a probiotic, VSL\# 3, on gut transit and symptoms in diarrhoea-predominant irritable bowel syndrome. Alimentary Pharmacol Ther. 2003;17(7):895-904.

38. Vinderola CG, Reinheimer JA. Lactic acid starter and probiotic bacteria: a comparative "in vitro" study of probiotic characteristics and biological barrier resistance. Food Res Int. 2003;36(9):895-904.

39. Van Loosdrecht MC, Lyklema J, Norde W, Schraa G, Zehnder AJ. The role of bacterial cell wall hydrophobicity in adhesion. Appl Environ Microbiol. 1987; 53(8):1893-7.

40. Bellon-Fontaine MN, Rault J, Van Oss CJ. Microbial adhesion to solvents: a novel method to determine the electron-donor/electron-acceptor or Lewis acid-base properties of microbial cells. Colloids Surface B. 1996;7(1):47-53.

41. Šušković J, Brkić B, Matošić S, Marić V. Lactobacillus acidophilus M92 as potential probiotic strain. Milchwissenschaft. 1997;52(8):430-5.

42. Shehata MG, El Sohaimy SA, El-Sahn MA, Youssef MM. Screening of isolated potential probiotic lactic acid bacteria for cholesterol lowering property and bile salt hydrolase activity. Ann Agri Sci. 2016;61:65-75.

43. Messner P, Sleytr UB. Crystalline bacterial cell-surface layers. Adv Microbial Physiol. 1992;33:213-75.

44. MacKenzie DA, Jeffers F, Parker ML, Vibert-Vallet A, Bongaerts RJ, Roos S. Strainspecific diversity of mucus-binding proteins in the adhesion and aggregation properties of Lactobacillus reuteri. Microbiol. 2010;156(11):3368-78.

45. Gruber K, Sleytr UB. Influence of an S-layer on surface properties of Bacillus stearothermophilus. Arch Microbiol. 1991;156(3):181-5.

46. Sillanpää J, Martínez B, Antikainen J, Toba T, Kalkkinen N, Tankka S. Characterization of the collagen-binding S-layer protein CbsA of Lactobacillus crispatus. J Bacteriol. 2000;182(22):6440-50.

47. Horie M, Ishiyama A, Fujihira-Ueki Y, Sillanpää J, Korhonen TK, Toba T. Inhibition of the adherence of Escherichia coli strains to basement membrane by Lactobacillus crispatus expressing an S-layer. J Appl Microbiol. 2002;92(3):396-403.

48. Johnson-Henry KC, Hagen KE, Gordonpour M, Tompkins TA, Sherman PM. Surface-layer protein extracts from Lactobacillus helveticus inhibit enterohaemorrhagic Escherichia coli 0157: H7 adhesion to epithelial cells. Cell Microbiol. 2007;9(2):356-67.

49. Embarek PK, Jeppesen VF, Huss HH. Antibacterial potential of Enterococcus faecium strains to inhibit Clostridium botulinum in sous-vide cooked fish fillets. Food Microbiol. 1994;11:525-36.

50. FAO/WHO, 2002. Joint FAO/WHO Working group report on drafting guidelines for the evaluation of probiotics in food London, Ontario, Canada, April 30 and May 1, 2002.

51. Maragkoudakis PA, Zoumpopoulou G, Miaris C, Kalantzopoulos G, Pot B, Tsakalidou E. Probiotic potential of Lactobacillus strains isolated from dairy products. Int Dairy J. 2006;16(3):189-99.

52. Argyri AA, Zoumpopoulou G, Karatzas K-LG, Tsakalidou E, Nychas G-JE, Panagou EZ, Tassou CC. Selection of potential probiotic lactic acid bacteria from fermented olives by in vitro tests. Food Microbiol. 2013;33:282-91.

53. Tamang JP, Tamang B, Schillinger U, Guigas C, Hlzapfel WH. Functional properties of lactic acid bacteria isolated from ethnic fermented vegetables of the Himalayas. Int J Food Microbiol. 2009;135:28-33.

54. Gobbetti M, Smacchi E, Corsetti A. Purification and characterisation of a cell surface-associated esterase from Lactobacillus fermentum DT41. Int Dairy J. 1997;7:13-21

55. Thapa N, Pal J, Tamang JP. Phenotypic identification and technological properties of lactic acid bacteria isolated from traditionally processed fish products of the eastern Himalayas. Int J Food Microbiol. 2006;107:33-8.

56. Thapa N, Pal J, Tamang JP. Microbial diversity in ngari, hentak and tungtap, fermented fish products of north-east India. World J Microbiol Biotechnol. 2004;20:599-607. 
57. Nanasombat S, Phunpruch S, Jaichalad T. Screening and identification of lactic acid bacteria from raw seafoods and Thai fermented seafood products for their potential use as starter cultures. Songklanakarin J Sci Technol. 2012;34(3): 255-62.

58. De Vuyst L. Technology aspects related to the application of functional starter cultures. Food Technol Biotechnol. 2000;38(2):105-12.

59. Tulini FL, Hymery N, Haertlé T, Blay GL, De Martinis ECP. Screening for antimicrobial and proteolytic activities of lactic acid bacteria isolated from cow, buffalo and goat milk and cheeses marketed in the southeast region of Brazil. J Dairy Res. 2015:1-10.

60. Biswas SR, Ray P, Johnson MC, Ray B. Influence of growth conditions on the production of a bacteriocin, pediocin AcH, by Pediococcus acidilactici $\mathrm{H}$. Appl Environmental Microbiol. 1991;57:1265-7.

61. Khairul Islam M, Abdul Alim Al-Bari M, Shakhawat Hasan M, Alam Khan M, Kudrat-E-Zahan M, Anwar UI Islam M. Synergistic inhibitory activities and enhancing antibiotic sensitivities of lactobacilli from rajshahi traditional curd. J Adv Bio Biotechnol. 2015;3(1):1-11.

62. Kivanc M, Yilmaz M, Çakir E. Isolation and identification of lactic acid bacteria from boza, and their microbial activity against several reporter strains. Turk J Bio. 2011;35:313-24.

63. Nespolo CR, Brandelli A. Production of bacteriocin-like substances by lactic acid bacteria isolated from regional ovine cheese. Braz J Microbiol. 2010;41: 1009-18.

64. Madrau MA, Mangia NP, Murgia MA, Sanna MG, Garau G, Leccis L, Caredda $M$, Deiana P. Employment of autochthonous microflora in Pecorino Sardo cheese manufacturing and evolution of physicochemical parameters during ripening. Int Dairy J. 2006;16:876-85.

65. Reddy G, Altaf M, Naveena BJ, Venkateshwar M, Kumar EV. Amylolytic bacterial lactic acid fermentation-a review. Biotechnol Adv. 2008;26:22-34.

66. Songré-Ouattara LT, Mouquet-Rivier C, Humblot C, Rochette I, Diawara B, Guyot JP. Ability of selected lactic acid bacteria to ferment a pearl milletsoybean slurry to produce gruels for complemen- tary foods for young children. J Food Sci. 2010;75:261-9.

67. Mukisa IM, Byaruhanga YB, Aijuka M, Schüller RB, Sahlstrøm S, Langsrud T, Narvhus JA. Influence of cofermentation by amylolytic Lactobacillus plantarum and Lactococcus lactis strains on the fermentation process and rheology of sorghum porridge. Appl Environ Microbiol. 2012;78(15):5220-8.

68. Putri WDR, Haryadi DW, Marseno-Cahyanto MN. Effect of biodegradation by lactic acid bacteria on physical properties of cassava starch. Int Food Res J. 2011;18:1149-54

69. Fossi BT, Tavea F, Jiwoua C, Ndjouenkeu R. Simultaneous production of raw starch degrading highly thermostable $a$-amylase and lactic acid by Lactobacillus fermentum 04BBA19. Afr J Biotechnol. 2011;10(34):6564-74.

\section{Submit your next manuscript to BioMed Central and we will help you at every step:}

- We accept pre-submission inquiries

- Our selector tool helps you to find the most relevant journal

- We provide round the clock customer support

- Convenient online submission

- Thorough peer review

- Inclusion in PubMed and all major indexing services

- Maximum visibility for your research

Submit your manuscript at www.biomedcentral.com/submit

C) Biomed Central 